\title{
Evidence that a West-East admixed population lived in the Tarim Basin as early as the early Bronze Age
}

\author{
Chunxiang Li ${ }^{1,2}$, Hongjie Li ${ }^{2}$, Yinqiu Cui ${ }^{1,2}$, Chengzhi Xie ${ }^{2}$, Dawei Cai ${ }^{1}$, Wenying Li ${ }^{3}$, Victor H Mair ${ }^{4}, Z_{\text {hi Xu }}{ }^{5}$,
} Quanchao Zhang ${ }^{1}$, Idelisi Abuduresule ${ }^{3}$, Li Jin ${ }^{4}$, Hong Zhu' ${ }^{1}$, Hui Zhou ${ }^{1,2^{*}}$

\begin{abstract}
Background: The Tarim Basin, located on the ancient Silk Road, played a very important role in the history of human migration and cultural communications between the West and the East. However, both the exact period at which the relevant events occurred and the origins of the people in the area remain very obscure. In this paper, we present data from the analyses of both $Y$ chromosomal and mitochondrial DNA (mtDNA) derived from human remains excavated from the Xiaohe cemetery, the oldest archeological site with human remains discovered in the Tarim Basin thus far.
\end{abstract}

Results: Mitochondrial DNA analysis showed that the Xiaohe people carried both the East Eurasian haplogroup (C) and the West Eurasian haplogroups ( $\mathrm{H}$ and $\mathrm{K}$ ), whereas $\mathrm{Y}$ chromosomal DNA analysis revealed only the West Eurasian haplogroup R1a1a in the male individuals.

Conclusion: Our results demonstrated that the Xiaohe people were an admixture from populations originating from both the West and the East, implying that the Tarim Basin had been occupied by an admixed population since the early Bronze Age. To our knowledge, this is the earliest genetic evidence of an admixed population settled in the Tarim Basin.

\section{Background}

The Tarim Basin in western China, positioned at a critical site on the ancient Silk Road, has played a significant role in the history of human migration, cultural developments and communications between the East and the West. It became famous due to the discovery of many well-preserved mummies within the area. These mummies, especially the prehistoric Bronze Age 'Caucasoid' mummies, such as the 'Beauty of Loulan', have attracted extensive interest among scientists regarding who were these people and where did they come from.

Based on analyses of human remains and other archaeological materials from the ancient cemeteries (dated from approximately the Bronze Age to the Iron Age), there is now widespread acceptance that the first residents of the Tarim Basin came from the West. This

\footnotetext{
* Correspondence: zhouhui@jlu.edu.cn

'Ancient DNA Laboratory, Research Center for Chinese Frontier Archaeology, Jilin University, Changchun 130012, PR China
}

was followed, in stages, by the arrival of Eastern people following the Han Dynasty $[1,2]$. However, the exact time when the admixture of the East and the West occurred in this area is still obscure [3]. In 2000, the Xinjiang Archaeological Institute rediscovered a very important Bronze Age site, the Xiaohe cemetery, by utilizing a device employing the global positioning system. The rediscovery of this cemetery provided an invaluable opportunity to further investigate the migrations of ancient populations in the region.

The Xiaohe cemetery $\left(40^{\circ} 20^{\prime} 11^{\prime \prime} \mathrm{N}, 88^{\circ} 40^{\prime} 20.3^{\prime \prime} \mathrm{E}\right)$ is located in the Taklamakan Desert of northwest China, about $60 \mathrm{~km}$ south of the Peacock River and $175 \mathrm{~km}$ west of the ancient city of Kroraina (now Loulan; Figure 1). It was first explored in 1934 by Folke Bergman, a Swedish archaeologist, but the cemetery was lost sight of until the Xinjiang Archaeological Institute rediscovered it in 2000. The burial site comprises a total of 167 graves. Many enigmatic features of these graves, such as the pervasive use of sexual symbolism 


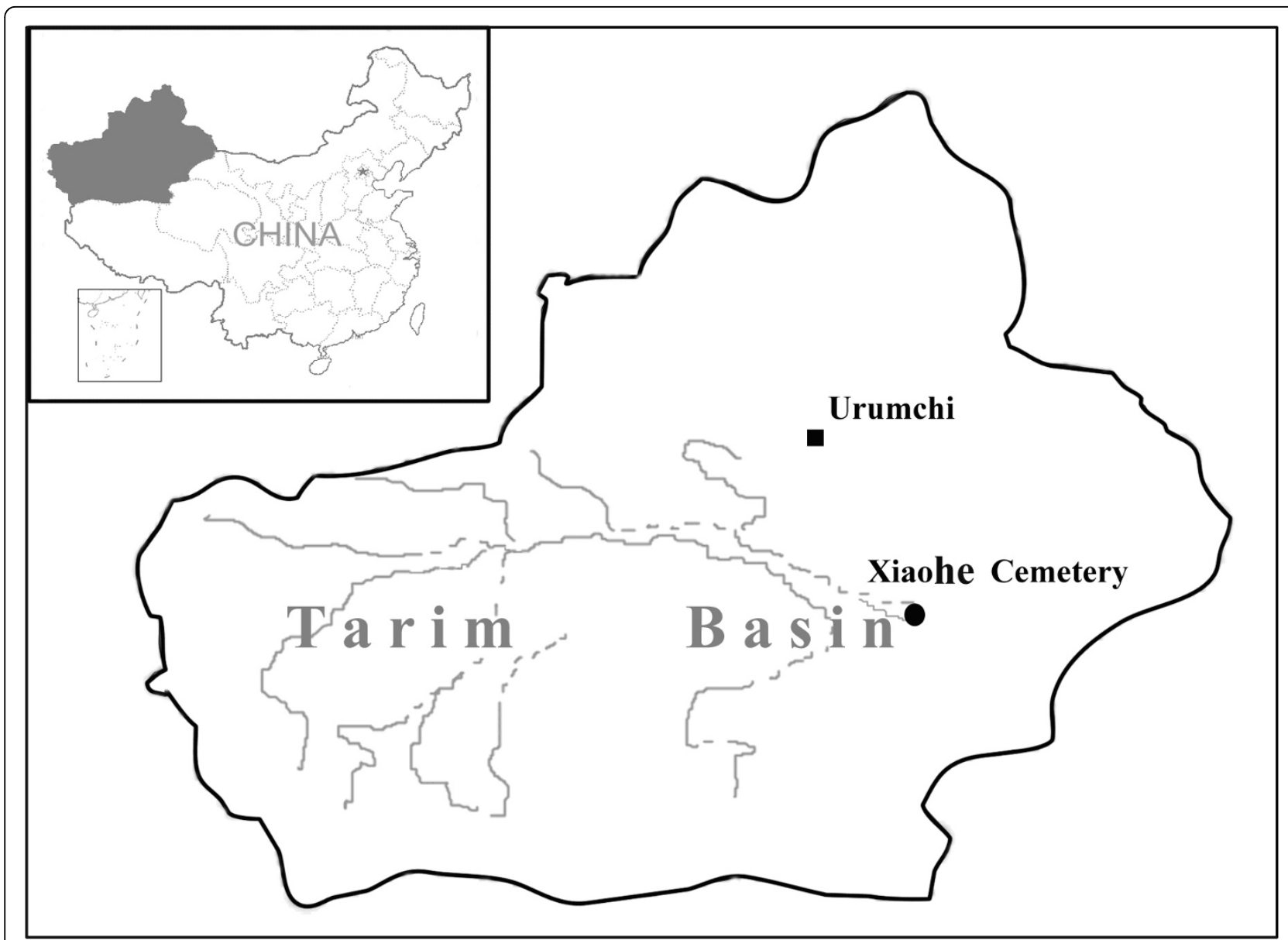

Figure 1 The geographical position of Xiaohe cemetery. The larger map shows Xinjiang, shown also in the shaded section of the map of China.

represented by tremendous numbers of huge phallusposts and vulvae-posts, exaggerated wooden sculptures of human figures and masks, well-preserved boat coffins and mummies, a large number of textiles, ornaments and other artifacts, show that the civilization revealed at Xiaohe is different from any other archaeological site of the same period anywhere in the world [3].

The entire necropolis can be divided, based on the archeological materials, into earlier and later layers. Radiocarbon measurement $\left({ }^{14} \mathrm{C}\right)$ dates the lowest layer of occupation to around $3980 \pm 40 \mathrm{BP}$ (personal communications; calibrated and measured by Wu Xiaohong, Head of the Laboratory of Accelerator Mass Spectrometry, Peking University), which is older than that of the Gumugou cemetery (dated to 3800). To date, these are the oldest human remains that have been excavated in the Tarim Basin [3]. A genetic study of these invaluable archeological materials will undoubtedly provide significant insights into the origins of the people of the Tarim Basin.

We examined the DNA profiles on both the maternal and the paternal aspects for all the morphologically well-preserved human remains from the lowest layer of the Xiaohe cemetery. We used these data to determine the population origins, to provide insights into the early human migration events in the Tarim Basin and, finally, to offer an expanded understanding of the human history of Eurasia.

\section{Methods}

\section{Sampling}

The excavation of the Xiaohe cemetery began in 2002. The lowest layer of the cemetery, comprising a total of 41 graves of which 37 have human skeletal remains, was excavated by the Xinjiang Archaeological Institute and the Research Center for Chinese Frontier Archaeology of Jilin University from 2004 to 2005. After the appropriate recording, the skeletal remains of 30 well-preserved individuals, together with sandy soil, were packed in cardboard boxes and sent to the ancient DNA laboratory of Jilin University, where they were stored in a dry and cool environment. All the samples were collected by two highly skilled scientists in our group, equipped with 
gloves and facemasks. As a result of the saline and alkaline character of the sand, the dry air and good drainage, the human remains are in excellent conditions. One intact femur and two tooth samples for each set of human remains were selected for DNA analysis, except for samples 84 and 121, which have only tooth samples. The archaeological information regarding the samples used in this study is summarized in Additional File 1.

\section{Contamination precautions and decontamination}

Previous studies have shown that the recovery of authentic ancient human DNA is possible $[4,5]$ when strict precautions are taken to prevent contamination. The following is a summary of the measures taken to avoid contamination and to ensure authenticity in the present study.

(1) Bone powdering, DNA extraction and amplification were carried out in three separate rooms in our laboratory which is dedicated solely to ancient DNA studies; all staff wore laboratory coats, facemasks and gloves and strict cleaning procedures [frequent treatment with bleach and ultraviolet (UV) light] were applied.

(2) In order to prevent contamination, polymerase chain reaction (PCR) tubes, tips, microcentrifuge tubes and drills were sterilized by autoclaving. Some of the reagents were exposed to UV light at $254 \mathrm{~nm}$ for at least $30 \mathrm{~min}$. Tip boxes were soaked in $10 \%$ sodium hypochlorite solution. Extraction and amplification blanks were included in every PCR assay in order to detect any potential contamination from sample processing or reagents even though they were guaranteed DNA-free by the manufacturers.

(3) Multiple extractions and amplifications from the same individual were undertaken at different times and from two different parts of the skeleton by three different laboratory members.

(4) Three samples were sent to Fudan University in Shanghai, China, for an independent repetition.

(5) Cloning analysis was performed with all the samples, in order to detect potential heterogeneity in the amplification products due to contamination, DNA damage or jumping PCR.

(6) Different length fragments were amplified. Since there is an inverse correlation between fragment length and amplification efficiency for ancient DNA, contamination from modern DNA could be identified by this assay.

(7) Ancient DNA from animal remains (goat or cattle) found at the same site was isolated and amplified using the same procedures as those used for the human ancient DNA, again providing a negative control for our study.

(8) The sex of some of the morphologically intact individuals was determined by amplifying the amelogenin (AMG) gene and the results were compared to that of the morphological examination in order to monitor any potential contamination in the extraction.

(9) DNA samples from all laboratory excavators and staff members involved in the project were genetically typed and recorded for comparison with the haplotypes of all ancient samples. This is critical in order to ensure the accuracy of the generated ancient DNA results [6-9]. The information for people involved in this project is listed in Table 1.

\section{Sample preparation and DNA extraction}

The bone and tooth samples were processed independently. A fragment of bone, about $3 \mathrm{~cm}$ long, was cut from the intact femur or tibia by sawing. In order to remove any possible surface contamination of the samples by external DNA, each bone was drilled three times with three different drills to remove a layer about 1-3 $\mathrm{mm}$ from the top after removing the external soil using brush, and then soaked in a $5 \%$ sodium hypochlorite solution for $10 \mathrm{~min}$, rinsed with distilled water and absolute alcohol successively and UV-irradiated (254 $\mathrm{nm}$ ) on all sides for at least $45 \mathrm{~min}$ in a clean room. The samples were then pulverized by Freezer Mill 6850

Table 1 Mitochondrial DNA haplotypes of all persons involved in processing Xiaohe samples.

\begin{tabular}{|c|c|c|c|}
\hline Investigators & Sex & HVRI polymorphism site & Appendix \\
\hline \multicolumn{4}{|l|}{ Excavators } \\
\hline 1 & Male & 161891622316278 & \\
\hline 2 & Male & 1609316124162231631116316 & \\
\hline 3 & Male & 162231629416362 & \\
\hline 4 & Male & 162231626016298 & * \\
\hline 5 & Male & 160921611116261 & \\
\hline 6 & Male & 1630016362 & \\
\hline 7 & Female & 16111161291626616304 & $*$ \\
\hline 8 & Male & 16221 & \\
\hline 9 & Male & 16126162941629616304 & \\
\hline 10 & Male & 160851620916311 & \\
\hline 11 & Male & 16356 & \\
\hline 12 & Male & 1613616356 & \\
\hline \multicolumn{4}{|l|}{$\begin{array}{l}\text { Laboratory } \\
\text { researchers }\end{array}$} \\
\hline 1 & Female & $\begin{array}{l}1613616183161891621716218 \\
1623916248\end{array}$ & * \\
\hline 2 & Female & 16223162451636216367 & \\
\hline 3 & Male & $\begin{array}{l}1618316189162231623416290 \\
16362\end{array}$ & \\
\hline 4 & Female & 1612616174162231631116362 & * \\
\hline 5 & Male & 161121622316362 & \\
\hline 6 & Male & 16213162231629816327 & \\
\hline 7 & Male & 1618916304 & \\
\hline
\end{tabular}

In the laboratory, the numbers 1, 2, 3 and 4 represent the staff participating in this study, 5, 6 and 7 represent the staff working in the laboratory but not directly concerned with this study. The *represents the primary researchers 
after immersion in liquid nitrogen. Intact teeth were handled differently: they were soaked in a $5 \%$ sodium hypochlorite solution for $15 \mathrm{~min}$ after a preliminary treatment in which they were wiped with $10 \%$ sodium hypochlorite and then rinsed with absolute alcohol. After that, all sides of the samples were exposed to UV radiation $(254 \mathrm{~nm})$ for a minimum of $20 \mathrm{~min}$ before the sample was ground to powder by Freezer Mill 6750 . DNA was extracted by means of a silica-based protocol [10]. One extraction blank was included for every three ancient samples. In brief, $0.5-2 \mathrm{~g}$ tooth/bone powder was incubated about $20 \mathrm{~h}$ at $50^{\circ} \mathrm{C}$ in lysis solution $(1$ $\mathrm{mL} \mathrm{10 \%} \mathrm{SDS,} 4 \mathrm{ml}$ EDTA (pH 8; 0.5 M, Promega, WI, USA), $100 \mathrm{uL}$ of $10 \mathrm{mg} / \mathrm{ml}$ proteinase K (Merck, Darmstadt, Germany). After centrifugation, the solution was subsequently concentrated with centricons (Millipore, MA, USA) up to about $100 \mu \mathrm{L}$ volume, and then the extraction proceeded according to the handbook of the QIAquick DNA Purification Kit (Qiagen, Hilden, Germany).

\section{DNA amplification, cloning, and sequencing}

The nucleotide positions 16035-16409 of the mitochondrial genome was amplified by two overlapping primer pairs. In addition, a number of coding-region mtDNA polymorphisms were typed, which are diagnostic for major branches in the mtDNA tree: Haplogroups $\mathrm{R}$ (12705C), UK(12308G), HV(14766T), H(7028C), R1 (4917G), R11(10031C) and C4(11969A) were identified by direct sequencing and haplogroups $\mathrm{M}(10400 \mathrm{~T}), \mathrm{F}$ (3970T) and C(14318C) were examined by using amplified product-length polymorphisms method [11-13]. The $B$ haplogroup was identified based on 9-bp deletion in np8280. Some Y-chromosomal single nucleotide polymorphisms (Y-SNPs) were typed, which are diagnostic for major branches in the $\mathrm{Y}$ chromosome haplogroup tree [14,15]: Haplogroups F(M89T), K(M9G), P(M45A), R1(M173A), and R1a1a(M198A) were identified by direct sequencing. The primers used in HVRI and diagnostic SNP markers are shown in Table 2.

PCR amplifications were performed in $20 \mu \mathrm{L}$ reactions with $3 \mu \mathrm{l}$ of extract, $1 \mathrm{U}$ Taq DNA polymerase (Fermentas, Ontario, Canada), and 1.5 $\times$ buffer (Fermentas), 1.5 $\mathrm{mg} / \mathrm{ml} \mathrm{BSA}, 2.5 \mathrm{mM} \mathrm{MgCl} 2,0.2 \mathrm{mM}$ dNTP (Promega, USA), and 400 pmol for each primer (Sangong, China). The cycle conditions used a Mastercycler gradient (Eppendorf, Germany) consisting of 40 cycles at $94^{\circ} \mathrm{C}$ for $1 \mathrm{~min}, 59^{\circ} \mathrm{C}-52^{\circ} \mathrm{C}$ for $1 \mathrm{~min}$, and $72^{\circ} \mathrm{C}$ for $1 \mathrm{~min}$, with a first denatured step of $94^{\circ} \mathrm{C}$ for $5 \mathrm{~min}$ and a last extended step of $72^{\circ} \mathrm{C}$ for $10 \mathrm{~min}$. PCR products were purified with QIAamp quick DNA Purification Kit (Qiagen) and sequenced with BigDye 3.1 in an ABI 310 DNA sequencer (Applied Biosystems, CA, USA). The PCR products were cloned with pGEM-T (Promega), following the supplier's instructions. Extraction, amplification, cloning, and sequencing were undertaken in slightly varying conditions for different samples (Table 3).

\section{Data analysis}

Sequence alignments were performed using the Clustalx1.8 software. Comparison of DNA sequence homology was performed with Blast from the National Centre for Biotechnology Information. Median networks were constructed by Network 4.5 using a reduction threshold and the different weights for SNPs loci but the same weight for all HVSI polymorphism loci. No statistical analysis was performed in this study due to the small sample size.

\section{Results}

\section{Authenticity of results}

A total of 23 reproducible mtDNA fragments (360 bp) were obtained from 30 individual sets of the Xiaohe human remains, after discarding seven samples due to failed amplification or irreproducible results. Three of the 23 DNA fragments were similar to the DNA of two people involved in the study and were also removed from the study, even though they yielded consistent results through three or more independent extractions.

The remains of 20 individuals were selected for cloning analysis. Eight to twelve clones from two independent amplifications of the 20 individuals were selected for automated DNA sequencing. Although a few positions were different from direct sequencing of the PCR products, which could be due to random Taq misincorporation or DNA damage, the consensus sequence from cloning was consistent (see Additional File 2). In order to validate the results generated in our laboratory, human remains from three Xiaohe individuals $(100,119$, and 127) were sent to the ancient DNA laboratory of Fudan University for further analysis and identical results were obtained.

The following facts further confirm the authenticity of our results: (1) an inverse correlation between the size of the PCR amplicons and the amplification efficiency for the Xiaohe samples (209 bp > 235 bp > 399 bp) was found; (2) molecular sexual identification results were in accordance with morphological sex assignments; (3) HVR-I sequences match well with the key coding region SNPs according to the well-defined mtDNA phylogenetic tree [16,17]; and (4) parallel studies were also performed on Xiaohe animal samples, and no human DNA was detected. Collectively, $20 \mathrm{mtDNA}$ fragments from 30 human remains were obtained that were inferred to be authentic (Table 3). The sequences have been submitted to GenBank with accession numbers FJ719792FJ719811. This high success rate suggests that the DNA from the Xiaohe human remains is well preserved, as 
Table 2 The primers used in this study.

\begin{tabular}{|c|c|c|c|}
\hline Haplogroup/AMG & Primer & SNP & Length \\
\hline HVRI-AB & $\begin{array}{l}\text { L16017 5'-TTCTCTGTTCTTTCATGGGGA } \\
\text { H16251 5'-GGAGTTGCAGTTGATGTGTGA }\end{array}$ & Sequencing & $235 \mathrm{bp}$ \\
\hline HVRI-CD & $\begin{array}{l}\text { L162015'-CAAGCAAGTACAGCAATCAAC } \\
\text { H16409 5'-AGGATGGTGGTCAAGGGA }\end{array}$ & Sequencing & $209 \mathrm{bp}$ \\
\hline M & $\begin{array}{l}\text { 10400T 5'-taattaTACAAAAAGGATTAGACTGtgCT } \\
\text { 10400C 5'-TACAAAAAGGATTAGACaGAACC } \\
\text { 10400R 5'-GAAGTGAGATGGTAAATGCTAG }\end{array}$ & 10400T & $149 \mathrm{bp} / 142 \mathrm{bp}$ \\
\hline $\mathrm{R}$ & $\begin{array}{l}\text { L12604 5'-ATCCCTGTAGCATTGTTCG } \\
\text { H12754 5'-GTTGGAATAGGTTGTTAGCG }\end{array}$ & $12705 \mathrm{C}$ & $151 \mathrm{bp}$ \\
\hline UK & $\begin{array}{l}\text { L12247 5'-TAACAACATGGCTTCTCAACT } \\
\text { H12377 5'-GAAGTCAGGGTTAGGGTGGT }\end{array}$ & $12308 \mathrm{G}$ & $132 \mathrm{bp}$ \\
\hline C & $\begin{array}{l}\text { L14318T 5'-CCTTCATAAATTATTCAGCTTCCaACACTAT } \\
\text { L14318C 5'-aaaaagctaCATAAATTATTCAGCTTCCTACtCTAC } \\
\text { H14318R 5'-TAAGTGGGTAGCGATGGA }\end{array}$ & $14318 \mathrm{C}$ & $110 \mathrm{bp} / 115 \mathrm{bp}$ \\
\hline C4 & $\begin{array}{l}\text { L11845 5'- AAGCCTCGCTAACCTCGCC } \\
\text { H12120 5'- GGGTGAGTGAGCCCCATTG }\end{array}$ & $11969 \mathrm{~A}$ & $176 \mathrm{bp}$ \\
\hline B & $\begin{array}{l}\text { L8215 5' ACAGTTTCATGCCCATCGTC' } \\
\text { H8297 5' ATGCTAAGTTAGCTTTACAG }\end{array}$ & $\begin{array}{l}\text { Coll/tRNAlys } \\
\text { 9-bp deletion }\end{array}$ & $121 \mathrm{bp} / 112 \mathrm{bp}$ \\
\hline R1 & $\begin{array}{l}\text { L4812 5'- GTCCCAGAGGTTACCCAAG } \\
\text { H4975 5'- CCACCTCAACTGCCTGCTA }\end{array}$ & $4917 \mathrm{G}$ & $164 \mathrm{bp}$ \\
\hline R11 & $\begin{array}{l}\text { L9920 5'- CGCCTGATACTGGCATTITGT } \\
\text { H101075' -GTAGTAAGGCTAGGAGGGTGTTG }\end{array}$ & $10031 \mathrm{C}$ & $188 \mathrm{bp}$ \\
\hline $\mathrm{HV}$ & $\begin{array}{l}\text { L14668 5'- CATCATTATTCTCGCACGG } \\
\text { H14831 5'- CGGAGATGTTGGATGGGGT }\end{array}$ & $14766 \mathrm{~T}$ & $164 \mathrm{bp}$ \\
\hline $\mathrm{F}$ & $\begin{array}{l}\text { 3970T 5' taaaaTGTATTCGGCTATGAAGAtTAA } \\
\text { 3970C 5' GTGTATTCGGCTATGAAGtATAG } \\
\text { 3970R 5' AGTCTCAGGCTTCAACATCG }\end{array}$ & 3970T & $70 \mathrm{bp} / 66 \mathrm{bp}$ \\
\hline $\mathrm{H}$ & $\begin{array}{l}\text { L6966 5'-GGCATTGTATTAGCAAACTCAT } \\
\text { H7118 5'-TAGGGTGTAGCCTGAGAATAG }\end{array}$ & $7028 C$ & $152 \mathrm{bp}$ \\
\hline AMG & $\begin{array}{l}\text { AMG1 5'-CCTGGGCTCTGTAAAGAATAG } \\
\text { AMG2 5'-CAGAGCTTAAACTGGGAAGCTG }\end{array}$ & & $115 \mathrm{bp} / 121 \mathrm{bp}$ \\
\hline Paternal hg F & $\begin{array}{l}\text { Forward 5' CCACAGAAGGATGCTGCTCA } \\
\text { Reverse r } 5^{\prime} \text { CACACTITGGGTCCAGGATCAC }\end{array}$ & M89T & $125 \mathrm{bp}$ \\
\hline Paternal hg K & $\begin{array}{l}\text { Forward 5' GGACCCTGAAATACAGAAC } \\
\text { Reverse 5' AAGCGCTACCTTACTTACAT }\end{array}$ & M9G & $128 \mathrm{bp}$ \\
\hline Paternal hg P & $\begin{array}{l}\text { Forward 5' GGGTGTGGACTITACGAAC } \\
\text { Reverse 5' AAATCCTACTATCTCCTGGC }\end{array}$ & M45A & $129 \mathrm{bp}$ \\
\hline Paternal hg R1 & $\begin{array}{l}\text { Forward 5' TTACTGTAACTTCCTAGAAAATTGG } \\
\text { Reverse 5' ATCCTGAAAACAAAACACTGG }\end{array}$ & M173C & $126 \mathrm{bp}$ \\
\hline Paternal hg R1a1a & $\begin{array}{l}\text { Forward 5' CTCTTTAAGCCATTCCAGTCA } \\
\text { Reverse 5' AAACATTACATGAGAAATTGCTG }\end{array}$ & M198A & $113 \mathrm{bp}$ \\
\hline
\end{tabular}

would be expected in samples originated from dry environmental conditions.

\section{MtDNA haplogroup profile and distribution}

The 20 mtDNA fragments containing eight different haplotypes that can be further assigned to five haplogroups, which belong to subhaplogroups of macrohaplogroups $\mathrm{M}$ and $\mathrm{N}$ (Figure 2).

The dominant haplogroup in the Xiaohe people was the East Eurasian lineage $\mathrm{C}$, shared by 14 Xiaohe individuals who were associated with two different mtDNA haplotypes (S1 and S2). According to the coding region $11969 \mathrm{G}$ to $\mathrm{A}$, all lineage $\mathrm{C}$ found in the Xiaohe people was further changed to subhaplogroup $\mathrm{C} 4$, which had
D-loop group-specific polymorphisms at nucleotide positions (np) 16298 ( $\mathrm{T}$ to $\mathrm{C}$ ) and 16327 (C to $\mathrm{T}$ ) [18]. Interestingly, the haplotype $\mathrm{S} 1$ shared by these 10 of the 14. Xiaohe individuals did not have the 16223T, a mutation had been found in the majority of modern lineage $\mathrm{C}$ populations. This haplotype was found merely in modern Evenks and Udegeys of southeastern Siberia but the frequency is low [18]. It is interesting to note that our study found a mutation, unique to the Xiaohe people but rare among lineage C, 16309 G (see Additional File 3). To the best of our knowledge, the lineage $C$ with $16309 \mathrm{G}$ was observed only in three people from modern central Asia to date, who also possess another two mutations in HVRI region [19]. 
Table 3 Analysis strategy of the samples.

\begin{tabular}{|c|c|c|c|c|c|c|}
\hline \multirow{2}{*}{$\begin{array}{c}\text { Sample } \\
\text { No. }\end{array}$} & \multirow{2}{*}{$\begin{array}{c}\text { MtDNA-HVRI } \\
\text { haplotype }\end{array}$} & \multirow{2}{*}{$\begin{array}{c}\text { MtDNA } \\
\text { haplogroup }\end{array}$} & \multirow{2}{*}{$\begin{array}{c}\text { Y chromosome } \\
\text { haplogroup }\end{array}$} & \multicolumn{2}{|c|}{ Sexing } & \multirow{2}{*}{$\begin{array}{c}\text { Independent } \\
\text { repetition }\end{array}$} \\
\hline & & & & Morphological & Molecular & \\
\hline 100 & $298-327$ & C4 & & Female & Female & $\sqrt{ }$ \\
\hline 102 & $298-327$ & C4 & & Female & - & \\
\hline 106 & $298-327$ & C4 & R1a1a & Male & Male & \\
\hline 107 & 223-298-309-327 & C4 & & Female & - & \\
\hline 109 & $298-327$ & C4 & & Female & - & \\
\hline 110 & $298-327$ & C4 & & Female & - & \\
\hline 111 & 223-298-309-327 & C4 & R1a1a & Male & Male & \\
\hline 115 & $298-327$ & C4 & R1a1a & Male & Male & \\
\hline 117 & 223-304 & $M^{*}$ & & Female & Female & \\
\hline 119 & $93-134-224-311-390$ & K & & Female & Female & $\sqrt{ }$ \\
\hline 120 & 189-192-311 & $\mathrm{R}^{*}$ & R1a1a & Male & Male & \\
\hline 121 & 183-189-192-311 & $\mathrm{R}^{*}$ & R1a1a & Male & Male & \\
\hline 127 & 223-298-309-327 & C4 & & Female & Female & $\sqrt{ }$ \\
\hline 128 & 260 & $\mathrm{H}$ & & Female & Female & \\
\hline 131 & 189-192-311-390 & $\mathrm{R}^{*}$ & & Female & Female & \\
\hline 132 & 298-327 & C4 & & Female & Female & \\
\hline 135 & 223-298-309-327 & C4 & & Female & Female & \\
\hline 136 & 298-327 & C4 & R1a1a & Male & Male & \\
\hline 138 & $298-327$ & C4 & - & Female & - & \\
\hline 139 & $298-327$ & C4 & R1a1a & Male & Male & \\
\hline
\end{tabular}

Note: $\sqrt{ }$ means we performed this kind of strategy to the sample; - indicates that the targeted DNA fragment could not be amplified for a given sample.

Besides the East Eurasian lineage, two West Eurasian mtDNA haplogroups $\mathrm{H}$ and $\mathrm{K}$ were found among the Xiaohe people. $\mathrm{H}$ lineage is the most common mtDNA haplogroup in West Eurasia [20], but haplogroup H with a $16260 \mathrm{~T}$ was shared by only nine modern people in Genbank, including one Italian, one German, one Hungarian, one Portuguese, one Icelander and four English people. Haplogroup K, a western Eurasian-specific haplogroup, is mainly distributed in Europe, central Asia, and Iran [20,21]. However, haplogroup K with $16134 \mathrm{~T}$, found in the Xiaohe people, has not been found in modern people to our knowledge.

Among the Xiaohe people, three sequences with the unique HVRI motif 16189-16192-16311 formed a subcluster (Figure 2) and were not shared by modern people. They are identified as macrohaplogroup $\mathrm{R}$ through sequencing the PCR amplicons at np10400 and np12705 in the coding region. The np12308, np14766, np10031, np4917, np3970, and 9 bp deletion, which are the diagnostic sites for the main subhaplogroups of $\mathrm{R}$, were further examined [15]. The results showed that they are related neither to the West Eurasian haplogroups UK, TJ, HV, R11 and R1, nor to the East Eurasian haplogroups B and F. So we designated them as haplogroup $R^{*}$ temporarily. Another sequence with motif 16223-16304, shared by some people from East Asia, India, and Europe, was assigned to haplogroup $M^{*}$.
$\mathrm{Y}$ chromosome haplogroup profiling and distribution

Fifteen individuals' AMG amplicons were obtained from the 20 Xiaohe individuals (whose mtDNA was successfully amplified), among which seven individuals were identified as male and eight as female. The Y chromosome haplogroup of the seven males were all assigned to haplogroup R1a1a through screening the Y-SNPs at M89, M9, M45, M173 and M198 successively. Haplogroup R1a1a is widely distributed in Eurasia: it is mainly found in Eastern Europe, Central Asia, South Asia, Siberia, ancient Siberia, but rare in East Asia [22-24].

\section{Discussion}

The Xiaohe cemetery is the oldest archeological site with human remains discovered in the Tarim Basin to date. Our genetic analyses revealed that the maternal lineages of the Xiaohe people were originated from both the East and the West, whereas paternal lineages discovered in the Xiaohe people all originated from the West.

The East Eurasian lineage C, which was widely distributed in modern Asian populations, was the dominant haplogroup in the remains recovered from the lowest layer of the Xiaohe cemetery. This lineage is most frequently found in modern Siberian populations (Evenks, Yakut, Evens, Tuvinian, Buryat, Koryak and Chukchi) and to a lesser extent in modern East Asian 


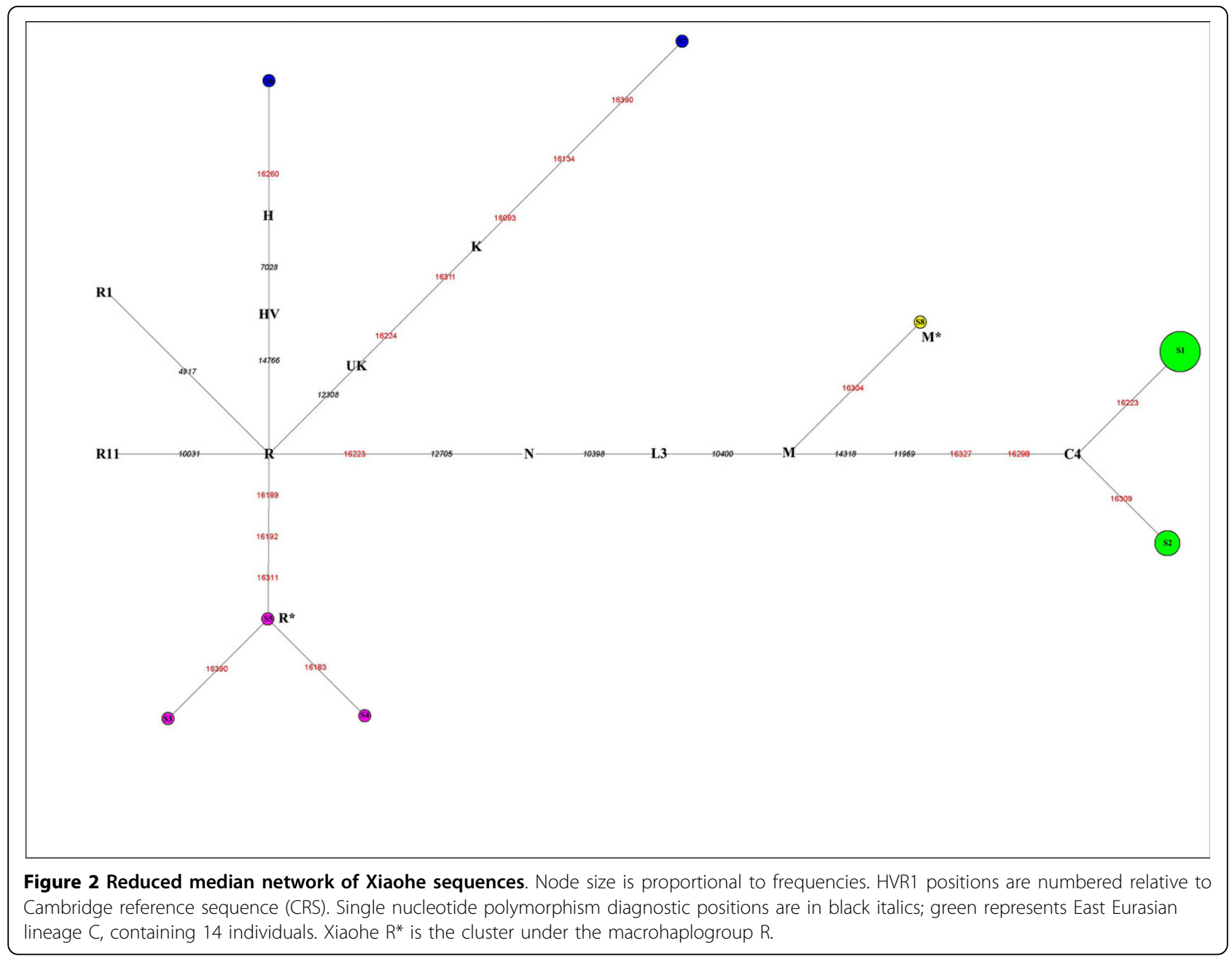

(Mongolian, Daur and Korean) and Central Asian populations [25-29] (Figure 3). It was also found in the ancient Qinghai (4000BP) of China [30] and ancient South Siberian populations [31,32]. In order to trace the original wellspring of lineage $\mathrm{C}$ in the Xiaohe population, a phylogenetic tree was constructed using 14 ancient Xiaohe samples and 522 modern haplogroup $C$ samples from surrounding areas of the Xiaohe cemetery, including Siberian, Mongolian, Central Asian, northern Chinese and northern minorities of East Asia (see Additional File 3). The phylogenetic network displays a star-like distribution within the South Siberian population, which has an ancestral haplotype motif 16223-16298-16327. The ancestral haplotype was found mainly in South Siberian whose diversity of haplotypes $C$ is very high (Figure 4). Therefore, the original source of haplogroup $C$ was inferred to South Siberian. It is important to note that the $C$ haplotypes of the Xiaohe people had only a single mutation compared with the ancestral haplotype. The shared sequences of the Xiaohe C haplotype (S1) were distributed in southeastern Siberia. It implies that the east Eurasian component in the Xiaohe people originated from the Siberian populations, especially the southern or eastern Siberian populations.

The mtDNA haplogroup $\mathrm{H}$ is the most common mtDNA haplogroup in Europe, especially in northwestern Europe, and its frequency can be as high as $65 \%$ in Iberia. Frequencies gradually decrease from the northwest to the southeast of Europe. By contrast, the frequency of haplogroup H rises to only $20 \%$ in the Near East, and to less than $10 \%$ in Central Asia, and is very low in East Asia [33,34]. All of the shared sequences of the Xiaohe $\mathrm{H}$ haplotype, however, were distributed in Western Europe. Haplogroup $\mathrm{K}$ is also common in Europe, particularly around the Alps and the British Isles. It is found with less frequency in North Africa, the Middle East, and South Asia [21,35-37]. Considering the presence of haplogroups $\mathrm{H}$ and $\mathrm{K}$ in the Xiaohe people and the geographical distribution of shared sequences, we conclude that the west Eurasian component observed in the Xiaohe people originated from western European, 


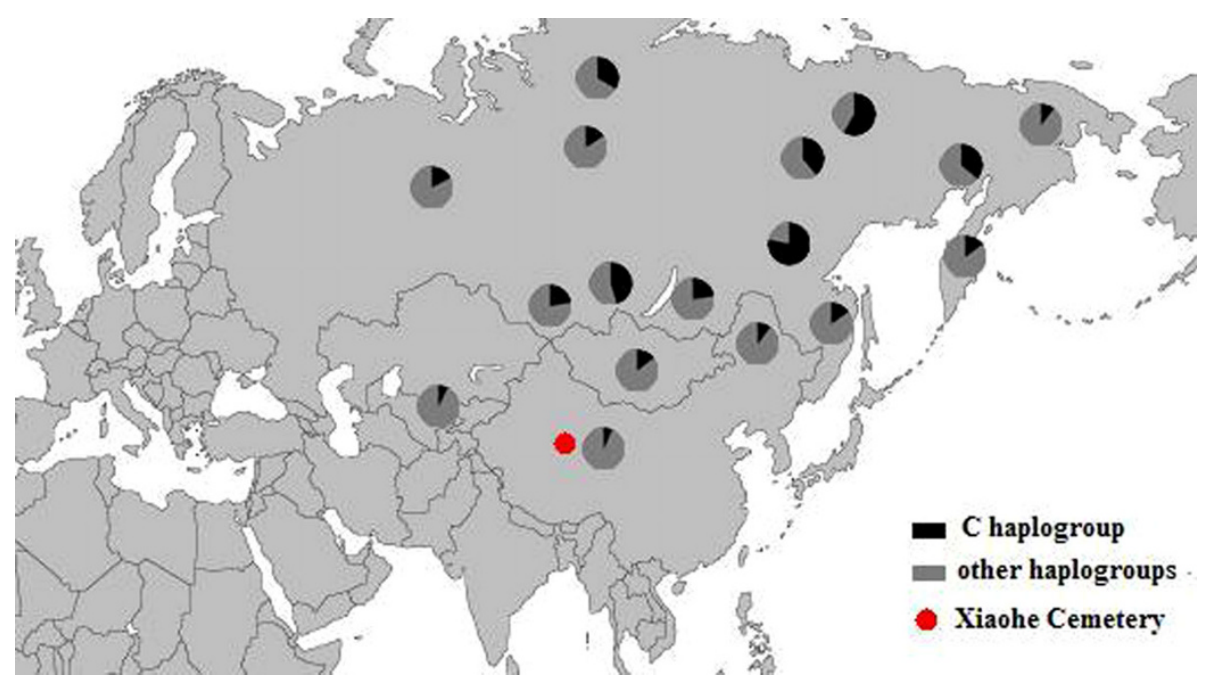

Figure 3 Map of Eurasia, showing the approximate distribution of haplogroup C. Black sections reflect the frequency of haplogroup C data taken from references listed in Additional File 3.

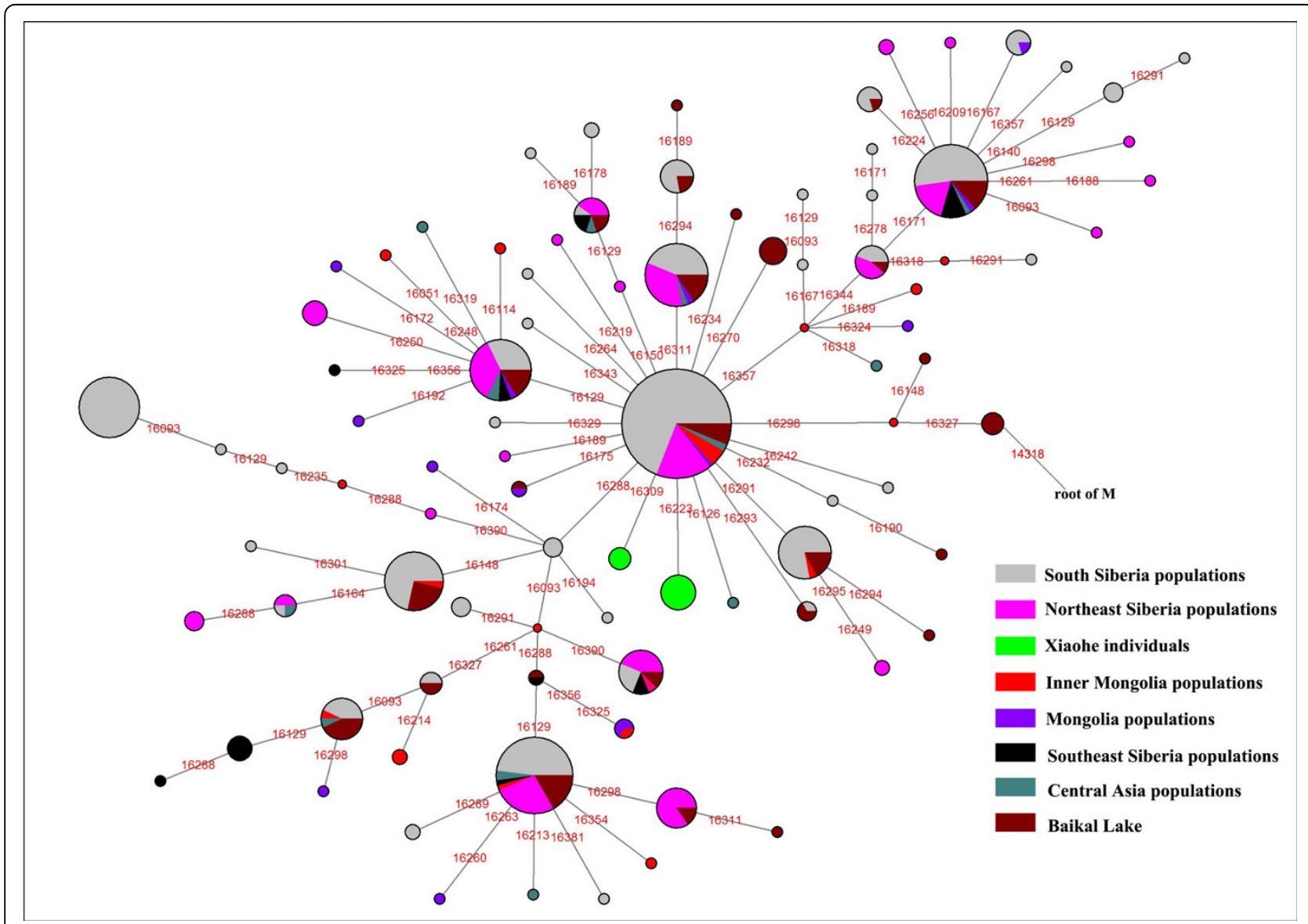

Figure 4 Phylogenetic tree of haplogroup C, based on HVS-I sequences in the region 16050-16391. For references for the mitochondrial DNA sequences in this study see Additional File 3 ; the length difference mutations were excluded from this analysis. 
and maternal ancestry of the Xiaohe people might have close relationship with western European.

Regarding the Y chromosomal DNA analyses, the seven males identified all belonged to haplogroup R1a1a. It is most frequently found in Eastern Europe, South Asia and Siberia. In contrast, it is relatively uncommon in Middle Easterners and rare in East Asian [22-24]. It is thought to be a trace of the migration events of early Indo-European [38,39]. The presence of haplogroup R1a1a in the ancient Xiaohe people implies that the parental ancestry of the Xiaohe people originated from somewhere in Siberia or Europe, which is consistent with the origin of maternal ancestry.

It is generally agreed that the origin of modern populations in Xinjiang and Central Asia is the result of the admixture of people from the West and the East $[19,25,40]$. When and where this admixture first occurred has long been of interest to geneticists and archaeologists [41-44]. The year $132 \mathrm{BC}$ is often considered to be the beginning of contact between the
East and the West along the Great Silk Road, since the Chinese explorer Zhang Qian went westward into Central Asia at that time. However, Mair has suggested that the date should be even earlier, based on the fact that silk appeared in Europe at 1000 BC [1]. In this study, the East and West Eurasian lineages are seen to coexist in the Xiaohe people, implying that the East had contacted the West during the early Bronze Age. It is noteworthy that the maternal lineage of five male individuals $(106,111,115,136$ and 139) originated from East Eurasian, whereas their paternal lineage originated from the West Eurasian, implying that the Xiaohe population had been an admixture of people from both the West and the East. Given the unique genetic haplotypes and the particular archaeological culture, the time of this admixture could be much earlier than the time at which the Xiaohe people were living at the site. This means that the time of their mingling was at least a 1000 years earlier than previously proposed.

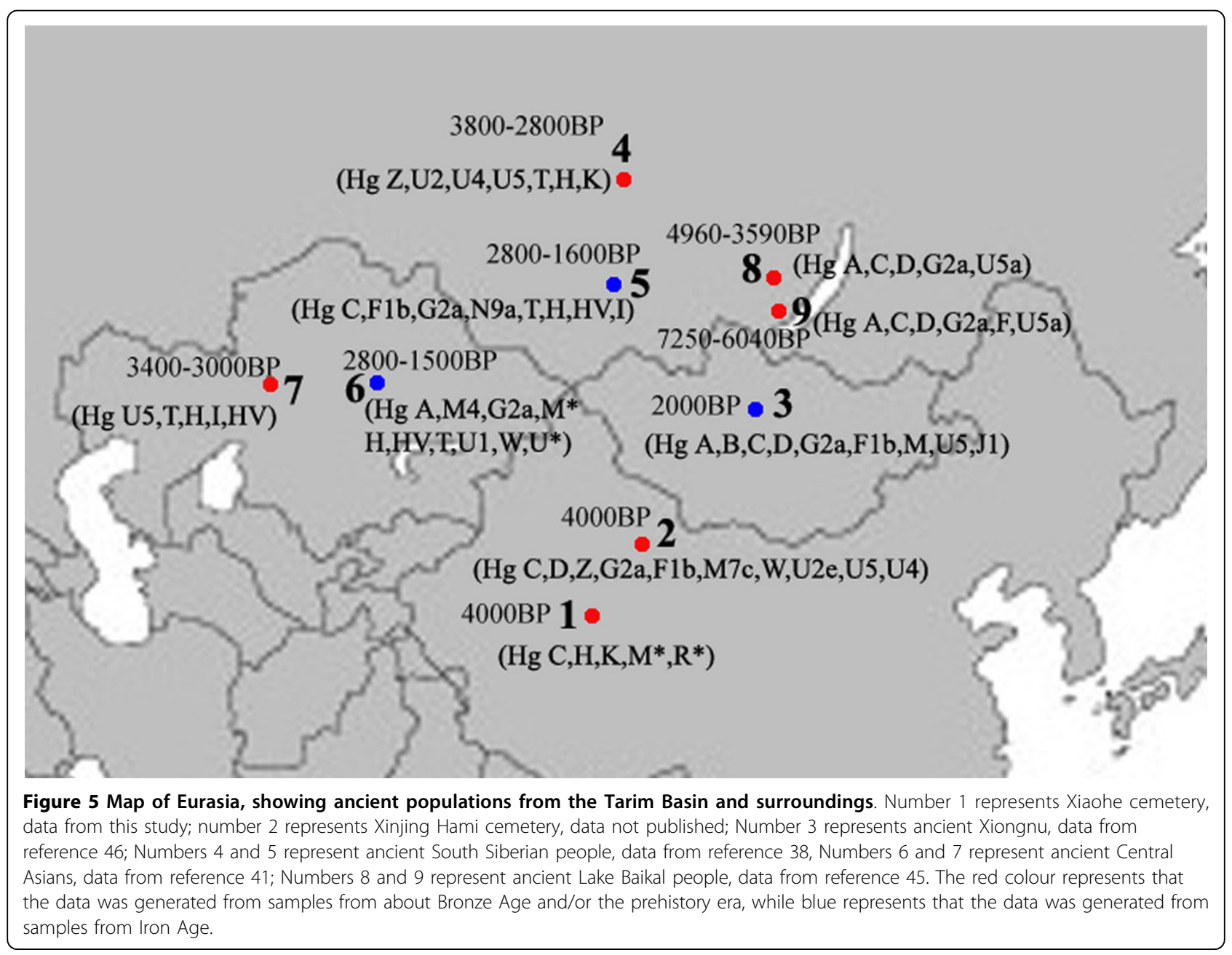


However, the mtDNA haplogroups $\mathrm{H}, \mathrm{K}$ and $\mathrm{C}$ all are very ancient lineages, over 10,000 years old in vast north Eurasia, whereas the civilization of the Tarim Basin, according to the archaeological materials, arose very late. The admixture therefore probably occurred elsewhere, before immigration into the Tarim Basin. The Xiaohe people might well have been an admixture at the time of their arrival. Where did the initial admixture occur?

The admixture from people of the West and the East was also found in ancient Central Asia, Siberia, and Mongolia [16,38,45,46]. The extent of the admixture varied in different regions and at different periods (Figure 5). Central Asia has always been the crossroads of contact between the West and the East. Lalueza-Fox et $a l$. proved that Eastern lineages coexisted with Western lineages in Central Asia after 700 BC [41], whereas the West had met the East in south Siberia in the Bronze Age [38], and even earlier at Lake Baikal [45]. Xinjiang and the surrounding areas, especially south Siberia, were places at which the contact between western and eastern populations occurred earlier than in Central Asia. Given the fact that the mtDNA haplogroup $C$ was distributed mainly in south Siberia, and that haplogroups $\mathrm{H}, \mathrm{K}$ and R1a1a already had spread eastward into south Siberia during the Bronze Age, it is possible that the initial admixture occurred somewhere in southern Siberia. Considering that the cultural characteristics of the Xiaohe cemetery are similar to those of the Andronovo or Afanasevo culture that appeared throughout the southern Russian steppe, Kazakhstan, and western Central Asia during the second millennium BC $[1,46]$, the admixed population might have had relationship with populations settled South Siberia during the Bronze Age.

\section{Conclusions}

Our results demonstrated that the Xiaohe people was an admixture from populations originating from both the West and the East, implying that the Tarim Basin had been occupied by an admixed population since the early Bronze Age. Considering the unique genetic haplotypes and particular archaeological culture, the admixed population might have had relationship with populations settled South Siberia during the Bronze Age. To our knowledge, this is the earliest genetic evidence of an admixed population settled in the Tarim Basin.

\footnotetext{
Additional file 1: Table S1. Archaeological information for 30 Xiaohe individuals.

Click here for file

[http://www.biomedcentral.com/content/supplementary/1741-7007-8-15S1.DOC ]
}

Additional file 2: Figure A1. The results of clone sequencing. Click here for file

[ http://www.biomedcentral.com/content/supplementary/1741-7007-8-15S2.PDF ]

Additional file 3: Table S2. Estimated frequencies of mitochondrial DNA haplogroup $\mathrm{C}$ in modern populations.

Click here for file

[ http://www.biomedcentral.com/content/supplementary/1741-7007-8-15S3.DOC]

\section{Abbreviations}

PCR: polymerase chain reaction; mtDNA: mitochondrial DNA: SNP: single nucleotide polymorphism; CRS: Cambridge reference sequence.

\section{Acknowledgements}

This work was supported by the National Natural Science Foundation of China, grant Nos: 30871349 and J0530184. We thank Xinjiang Cultural Relics and the Archaeology Institute, for providing the human remains and the School of Life Sciences, Fudan University, for the independent replication. Our special thanks go to Professor Yubin Ge for reading and commenting on the manuscript.

\section{Author details}

'Ancient DNA Laboratory, Research Center for Chinese Frontier Archaeology, Jilin University, Changchun 130012, PR China. ${ }^{2}$ College of Life Science, Jilin University, Changchun 130023, PR China. ${ }^{3}$ Xinjiang Cultural Relics and Archaeology Institute, Ürümchi 830000, PR China. ${ }^{4}$ Department of East Asian Languages and Civilizations, University of Pennsylvania, Philadelphia, PA 19104, USA. ${ }^{5}$ Key Laboratory of Genetic Engineering and Center for Anthropological Studies, School of Life Sciences, Fudan University, Shanghai 200433, PR China.

\section{Authors' contributions}

$C X L$ and HJL contributed equally to this work, they performed the molecular genetic studies and data analysis and wrote the manuscript. YQC and VHM helped to draft the manuscript. CZX and DWC participated in performing experiments. WYL and IA provided materials and background documents. QCZ participated in the statistical analysis. ZX and $\amalg$ provided independent replication. $\mathrm{HZ}$ participated in conceiving and designing the study. $\mathrm{HZ}$ designed the study and wrote the manuscript. All authors read and approved the final manuscript.

\section{Received: 21 September 2009}

Accepted: 17 February 2010 Published: 17 February 2010

\section{References}

1. Mair VH: Prehistoric Caucasoid corpses of the Tarim Basin. J Indo Eur Stud 1995, 23:281-307.

2. Hemphill BE, Mallory JP: Horse-mounted invaders from the Russo-Kazakh steppe or agricultural colonists from western Central Asia? A craniometric investigation of the Bronze Age settlement of Xinjiang. Am J Phys Anthropol 2004, 124:199-222.

3. Mair VH: The rediscovery and complete excavation of Ördek's Necropolis. If Indo-European Stud 2006, 34(3-4):273-318.

4. Cooper A, Poinar HN: Ancient DNA: do it right or not at all. Science 2000, 289:1139.

5. Haak W, Forster P, Bramanti B, Matsumura S, Brandt G, Tänzer M, Villems R, Renfrew C, Gronenborn D, Alt KW, Burger J: Ancient DNA from the first European farmers in 7500-Year-Old Neolithic Sites. Science 2005, 310:1016-1018.

6. Pääbo S, Poinar H, Serre D, Jaenicke-Despres V, Hebler J, Rohland N, Kuch M, Krause J, Vigilant L, Hofreiter M: Genetic analyses from ancient DNA. Annu Rev Genet 2004, 38:645-679.

7. Willerslev E, Cooper A: Ancient DNA. Proc R Soc B 2005, 272:3-16.

8. Sampietro ML, Gilbert MT, Lao O, Caramelli D, Lari M, Bertranpetit J, Lalueza-Fox C: Tracking down human contamination in ancient human teeth. Mol Biol Evol 2006, 23:1801-1807. 
9. Xie CZ, Li CX, Cui YQ, Zhang QC, Fu YQ, Zhu H, Zhou H: Evidence of ancient DNA reveals the first European lineage in Iron Age central China. Proc Biol Sci 2007, 274:1597-1602.

10. Yang DY, Eng B, Waye JS, Dudar JC, Saunders SR: Improved DNA extraction from ancient bones using silica-based spin columns. Am J Phys Anthropol 1998, 105:539-543.

11. Shinoda K, Adachi N, Guillen S, Shimada I: Mitochondrial DNA analysis of ancient Peruvian highlanders. Am J Phys Anthropol 2006, 131(1):98-107.

12. Van Oven $M$, Kayer $M$ : Updated compnenensive phylogenetic tree of global human mitochontrial DNA Variation. Hum Mutat 2009, 30(2): E386-E394.

13. Malyarchuk B, Grzybowski T, Derenko M, Perkova M, Vanecek T, Lazur J, Gomolcak P, Tsybovsky I: Mitochondrial DNA phylogeny in Eastern and Western Slavs. Mol Biol Evol 2008, 25(8):1651-1658.

14. Underhill PA, Myres NM, Rootsi S, Metspalu M, Zhivotovsky LA, King RJ, Lin AA, Chow CE, Semino O, Battaglia V, Kutuev I, Järve M, Chaubey G, Ayub Q, Mohyuddin A, Mehdi SQ, Sengupta S, Rogaev El, Khusnutdinova EK, Pshenichnov A, Balanovsky O, Balanovska $E_{\text {, Jeran } N}$ Augustin DH, Baldovic M, Herrera RJ, Thangaraj K, Singh V, Singh L, Majumder $P$, Rudan $P$, Primorac D, Villems R, Kivisild T: Separating the post-Glacial coancestry of European and Asian $Y$ chromosomes within haplogroup R1a. Eur J Hum Genet 2009, doi:10.1038.

15. Karafet TM, Mendez FL, Meilerman MB, Underhill PA, Zegura SL, Hammer MF: New binary polymorphisms reshape and increase resolution of the human Y-chromosomal haplogroup tree. Genome Res 2008, 18(5):830-838.

16. Macaulay V, Richards M, Hickey E, Vega E, Cruciani F, Guida V, Scozzari R, Bonné-Tamir B, Sykes B, Torroni A: The emerging tree of West Eurasian mtDNAs: a synthesis of control-region sequences and RFLPs. Am J Hum Genet 1999, 64:232-249.

17. Kivisild T, Tolk HV, Parik J, Wang Y, Papiha SS, Bandelt HJ, Villems R: The emerging limbs and twigs of the East Asian mtDNA tree. Mol Biol Evol 2002, 19:1737-1751.

18. Torroni A, Schurr TG, Cabell MF, Brown MD, Neel JV, Larsen M, Smith DG Vullo CM, Wallace DC: Asian affinities and continental radiation of the four founding Native American mtDNAs. Am J Hum Genet 1993 53:563-590.

19. Comas D, Calafell F, Mateu E, Pérez-Lezaun A, Bosch E, Martínez-Arias R, Clarimon J, Facchini F, Fiori G, Luiselli D, Pettener D, Bertranpetit J: Trading genes along the Silk Road: mitochondrial DNA sequences and the origin of Central Asian populations. Am J Hum Genet 1998, 63:1824-1838

20. Torroni A, Richards M, Macaulay V, Forster P, Villems R, Norby S, Savontaus ML, Huoponen K, Scozzari R, Bandelt HJ: MtDNA haplogroups and frequency patterns in Europe. Am J Hum Genet 2000, 66:1173-1177.

21. Kivisild T, Bamshad MJ, Kaldma K, Metspalu M, Metspalu E, Reidla M, Laos S, Parik J, Watkins WS, Dixon ME, Papiha SS, Mastana SS, Mir MR, Ferak V, Villems R: Deep common ancestry of Indian and western-Eurasian mitochondrial DNA lineages. Curr Biol 1999, 9:1331-1334.

22. Comas D, Plaza S, Wells RS, Yuldusheva N, Lao O, Calafell F, Bertranpetit J: Admixture, migrations, and dispersals in Central Asia: evidence from maternal DNA lineages. Eur J Hum Genet 2004, 12(6):495-504.

23. Koryakova LN, Epimakhov AV: The Urals and Western Siberia in the Bronze and Iron Ages. Cambridge: Cambridge University Press 2007.

24. Balanovsky O, Rootsi S, Pshenichnov A, Kivisild T, Churnosov M, Evseeva I, Pocheshkhova E, Boldyreva M, Yankovsky N, Balanovska E, Villems R: Two Sources of the Russian Patrilineal Heritage in Their Eurasian Context. Am J Hum Genet 2008, 82(1):236-250.

25. Sharma S, Rai E, Sharma $P$, Jena M, Singh S, Darvishi K, Bhat AK, Bhanwer AJ, Tiwari PK, Bamezai RN: The Indian origin of paternal haplogroup R1a1 $\left(^{*}\right)$ substantiates the autochthonous origin of Brahmins and the caste system. J Hum Genet 2009, 54(1):47-55.

26. Torroni A, Sukernik RI, Schurr TG, Starikorskaya YB, Cabell MF, Crawford MH, Comuzzie AG, Wallace DC: mtDNA variation of aboriginal Siberians reveals distinct genetic affinities with Native Americans. Am J Hum Genet 1993, 53:591-608.

27. Starikovskaya EB, Sukernik RI, Derbeneva OA, Volodko NV, Ruiz-Pesini E, Torroni A, Brown MD, Lott MT, Hosseini SH, Huoponen K, Wallace DC: Mitochondrial DNA diversity in indigenous populations of the southern extent of Siberia, and the origins of Native American haplogroups. Ann Hum Genet 2005, 69:67-89.
28. Kolman CJ, Sambuughin N, Bermingham E: Mitochondrial DNA analysis of Mongolian populations and implications for the origin of New World founders. Genetics 1996, 142(4):1321-1334.

29. Kong Q-P, Yao Y-G, Liu M, Shen S-P, Chen C, Zhu C-L, Palanichamy MG Zhang Y-P: Mitochondrial DNA sequence polymorphisms of five ethnic populations from northern China. Hum Genet 2003, 113:391-405.

30. Gao SZ, Yang YD, Xu Y, Zhang QC, Zhu H, Zhou H: Tracing the genetic history of the Chinese people: Mitochondrial DNA analysis of a neolithic population from the Lajia site. Am J Phys Anthropol 2007, 133:1128-1136.

31. Ricaut FX, Fedoseeva A, Keyser-Tracqui C, Crubézy E, Ludes B: Ancient DNA analysis of human neolithic remains found in northeastern Siberia. Am J Phys Anthropol 2005, 126:458-462.

32. Schurr TG: Molecular genetic diversity of Siberian populations: Implications for ancient DNA studies of archeological populations from the Cis-Baikal region. Prehistoric Foragers of the Cis-Baikal, Siberia: Proceedings from the First Conference of the Baikal Archaeology Project Canadian Circumpolar Institute: EdmontonMcKenzie H, Weber A 2003, 153-186.

33. Achilli A, Rengo C, Magri C, Battaglia V, Olivieri A, Scozzari R, Cruciani F, Zeviani M, Briem E, Carelli V, Moral P, Dugoujon JM, Roostalu U, Loogväli EL, Kivisild T, Bandelt HJ, Richards M, Villems R, SantachiaraBenerecetti AS, Semino O, Torroni A: The molecular dissection of mtDNA haplogroup $\mathrm{H}$ confirms that the Franco-Cantabrian glacial refuge was a major source for the European gene pool. Am J Hum Genet 2004 75(5):910-918.

34. Simoni L, Calafell F, Pettener D, Bertranpetit J, Barbujani G: Geographic patterns of mtDNA diversity in Europe. Am J Hum Genet 2000, 66:262-278.

35. Richards M, Macaulay V, Hickey E, Vega E, Sykes B, Guida V, Rengo C, Sellitto D, Cruciani F, Kivisild T, Villems R, Thomas M, Rychkov S, Rychkov O, Rychkov Y, Gölge M, Dimitrov D, Hill E, Bradley D, Romano V, Cali F, Vona G, Demaine A, Papiha S, Triantaphyllidis C, Stefanescu G, Hatina J, Belledi M, Di Rienzo A, Novelletto A, Oppenheim A, Nørby S, Al-Zaheri N, SantachiaraBenerecetti S, Scozari R, Torroni A, Bandelt HJ: Tracing European founder lineages in the Near Eastern mtDNA pool. Am J Hum Genet 2000, 67(5):1251-1276

36. Picornell A, Giménez P, Castro JA, Ramon MM: Mitochondrial DNA sequence variation in Jewish populations. Int J Legal Med 2006 120(5):271-281.

37. Behar DM, Metspalu E, Kivisild T, Achilli A, Hadid Y, Tzur S, Pereira L, Amorim A, Quintana-Murci L, Majamaa K, Herrnstadt C, Howell N, Balanovsky O, Kutuev I, Pshenichnov A, Gurwitz D, Bonne-Tamir B, Torroni A, Villems R, Skorecki K: The matrilineal ancestry of Ashkenazi Jewry: portrait of a recent founder event. Am J Hum Genet 2006, 78(3):487-497

38. Keyser C, Bouakaze C, Crubézy E, Nikolaev VG, Montagnon D, Reis T, Ludes B: Ancient DNA provides new insights into the history of south Siberian Kurgan people. Hum Genet 2009, 126(3):395-410.

39. Semino O, Passarino G, Oefner PJ, Lin AA, Arbuzova S, Beckman LE, De Benedictis G, Francalacci P, Kouvatsi A, Limborska S, Marcikiae M, Mika A, Mika B, Primorac D, Santachiara-Benerecetti AS, Cavalli-Sforza LL, Underhill PA: The genetic legacy of Paleolithic Homo sapiens sapiens in extant Europeans: a Y chromosome perspective. Science 2000, 290:1155-1159.

40. Yao YG, Kong QP, Wang CY, Zhu CL, Zhang YP: Different matrilineal contributions to genetic structure of ethnic groups in the silk road region in China. Mol Biol Evol 2004, 21(12):2265-2280.

41. Lalueza-Fox C, Sampietro ML, Gilbert MT, Castri L, Facchini F, Pettener D, Bertranpetit J: Unravelling migrations in the steppe: mitochondrial DNA sequences from ancient Central Asians. Proc Biol Sci 2004, 271:941-947.

42. Mair VH: Genes, geography, and glottochronology: the Tarim Basin during late prehistory and history. The Journal of Indo-European Studies Monograph Series. No. 50 Washington DC: Institute for the Study of Man 2005, 1-47.

43. Francalacci P: DNA analysis of ancient desiccated corpses from Xinjiang. $J$ Indo Eur Stud 1995, 23:385-398.

44. Francalacci P: DNA analysis on ancient desiccated corpses from Xinjiang (China): further results. The Bronze Age and Early Iron Age Peoples of Eastern Central Asia Washington, DC: Institute for the Study of ManMair VH 1998, 537-547. 
45. Mooder KP, Schurr TG, Bamforth FJ, Bazaliiski VI, Savel'ev NA: Population affinities of neolithic Siberians: a snapshot from prehistoric Lake Baikal. Am J Phys Anthropol 2006, 129:349-361.

46. Keyser-Tracqui C, Crubézy E, Ludes B: Nuclear and mitochondrial DNA analysis of a 2,000-year-old necropolis in the Egyin Gol Valley of Mongolia. Am J Hum Genet 2003, 73(2):247-260.

doi:10.1186/1741-7007-8-15

Cite this article as: $L i$ et al:: Evidence that a West-East admixed population lived in the Tarim Basin as early as the early Bronze Age. BMC Biology 2010 8:15.

Submit your next manuscript to BioMed Central and take full advantage of:

- Convenient online submission

- Thorough peer review

- No space constraints or color figure charges

- Immediate publication on acceptance

- Inclusion in PubMed, CAS, Scopus and Google Scholar

- Research which is freely available for redistribution

Submit your manuscript at www.biomedcentral.com/submit
C Biomed Central 